\title{
POSISI AL-QUR’AN DALAM EPISTIMOLOGI HERMENEUTIKA
}

\author{
Kamarusdiana, ${ }^{1}$ Ahmad Zaki $\mathbf{M}^{2}$ \\ ${ }^{1}$ UIN Syarif Hidayatullah Jakarta \\ kamarusdiana@uinjkt.ac.id \\ ${ }^{2}$ UIN Syarif Hidayatullah Jakarta \\ a.zakimuntafi@gmail.com
}

\begin{abstract}
The interpretation of the scriptural texts, including the Quran in them, received more attention in scientific dynamics. This attention was born over the discovery of the invalidity of meaning in the text of the Scriptures. Moreover, the results of relative interpretations can lead to speculation of new meanings which will basically continue to develop depending on who the interpreter is. In this matter, present hermeneutics responds to the problem of interpreting the Scriptures. The Quran as a sacred text also has a place in hermeneutics. However, the problem that arises later is the chaos within Islam itself which concerns the hermeneutic method, which is considered a western product. In this case, there is controversy over rejection and acceptance of hermeneutics. This paper will try to examine hermeneutics in Islam, where it sketches the position of the Koran in hermeneutic interpretation, and tries to initiate hermeneutics as a new alternative to interpretation.
\end{abstract}

Keywords: al-Quran, Epistimology, Hermeneutics

\begin{abstract}
ABSTRAK
Penafsiran teks-teks kitab Suci, termasuk Alquran didalamnya mendapat perhatian lebih dalam dinamika keilmuan. Perhatian ini lahir atas ditemukannya ketidakbakuan makna dalam teks Kitab Suci. Terlebih lagi hasil dari penafsiran yang bersifat relatif dapat menimbulkan spekulasi makna baru yang pada dasarnya akan terus berkembang tergantung pada siapa penafsirnya. Dalam persoalan ini, hermeneutika hadir merespon problem penafsiran teks Kitab Suci. Al-Quran sebagai teks suci juga mendapat tempat didalam hermeneutika. Akan tetapi, persoalan yang mucul kemudian adalah kemelut didalam Islam sendiri yang mempersoalkan metode hermeneutika, di mana dianggap sebagai produk barat. Dalam hal ini, terjadi kontroversi penolakan dan penemerimaan hermeneutika. Tulisan ini akan mencoba mengupas hermeneutika dalam Islam, di mana mensketsakan posisi Alquran dalam penafsiran hermeneutika, serta mencoba menggagas hermeneutika sebagai alternatif baru dalam penafsiran.
\end{abstract}

\section{A. PENDAHULUAN}

Model penafsiran al-Quran telah mengalami fluktuasi perkembangan secara sisi ilmiah. Berbagai model yang telah diperkenalkan mengalami pasang surut secara bergantian mewarnai penafsiran teks-teks keagamaan, termasuk al-Quran di dalamnya. Persoalan ini pada dasarnya lahir atas titik temu dalam memahami teks-teks agama. Hal ini dilakukan untuk melakukan penilaian dan pemahaman atas maksud dari teks tersebut sebagai sebuah ajaran agama yang harus diyakini dan diamalkan dalam keseharian. 
Teks-teks agama secara umum dipahami sebagai teks yang memiliki nilai sakralitas. Pemahaman ini muncul berdasarkan asal muasal lahirnya teks keagamaan yang dipandang sebagai wahyu Tuhan. Dalam pandangan Komarudin Hidayat, sakralisasi sangat diperlukan bagi orang awam agar tidak bingung dalam memahami teks keagamaan. Tetapi, jika sudah mengalami pendewasaan diri terhadap agama, justru sakralisasi tersebut dapat mempersempit agama (Islam) itu sendiri. ${ }^{1}$

Persoalaan kesucian teks keagamaan memang muskil untuk ditolak. Agama sebagai pengejawantahan ajaran Tuhan tentu membutuhkan legitimasi totalitas, termasuk kaitannya dengan teks sucinya. Jika legitimasi tersebut hanya parsial, maka persoalan keimanan akan ditanyakan dan diragukan. Legitimasi totalitas ini sebagai bentuk keimanan.

Sebagai sebuah teks, al-Quran tidak pernah kering untuk ditafsirkan. Teks di dalam al-Quran bisa ditafsirkan secara kaya, tergantung dengan konteks sosial budaya, struktur nilai, dan kesadaran pembacanya. Dengan demikian, menurut pandangan Nasr Hamid Abu Zaid persentuhan antara penafsir dengan al-Quran merupakan pergulatan yang dinamis, bahkan sering tidak terduga. ${ }^{2} \mathrm{Di}$ sini al-Quran tidak pernah berhenti dan membeku, tetapi selalu mengajak penafsirnya untuk mencari dan menjelajah lebih dalam.

Penafsiran al-Quran dalam tradisi keilmuan Islam tidak terlepas dari tafsir dan ta'wil. Namun, perkembangan model penafsiran semakin berkembang pesat. Hingga kemudian lahir istilah hermeneutika yang mengupayakan penafsiran akan teks-teks. Metode hermeneutika ini kemudian mendapat wacana untuk mendapat tempat pada penafsiran al-Quran. Meskipun lahir dari barat, eksistensi hermeneutika mengakaji teks Kitab Suci cukup memberikan sebuah alternatif, tentunya tidak terlepas dari proses pergelutan dan dinamika ilmiah yang akan terjadi.

\section{B. MENGENAL KONSEP DASAR HERMENEUTIKA}

Secara etimologis, hermeneutika berasal dari bahasa Yunani, yakni hermeneuein yang berarti menafsirkan atau menginterpretasi. Selain itu, kata hermeneuein berasal dari bahasa Greek hermeneutikos. ${ }^{3}$ Maka, jika dilihat sebagai kata benda, yakni hermenia yang berarti penafsiran atau interpretasi. ${ }^{4}$ Dari kata kerja hermeneuein dapat ditarik tiga bentuk makna dasar dalam koridor makna aslinya, yakni mengungkapkan, menjelaskan, dan menerjemahkan. Namun, masing-masing makna tersebut memiliki independensi dan signifikansi bagi interpretasi. ${ }^{5}$ Pemahaman makna interpretasi dari konteks hermeneutika mengandung pengertian sebagai pengucapan lisan, penjelasan yang dapat diterima akal, serta penyalinan dari satu bahasa ke bahasa lain. ${ }^{6}$ Dalam konteks studi al-Quran, hermeneutika lebih dikenal sebagai tafsir, ta 'wil, sharh, dan bayan. ${ }^{7}$

Secara susunan bahasa terdapat perbedaan antara hermeneutik (hermeneutic) dan hermeneutika (hermeneutics). Hermeneutik merupakan kata adjektif yang mengandung

1 Komarudin Hidayat, Wahyu di Langit, Wahyu di Bumi: Doktrin dan Peradaban Islam di Panggung Sejarah (Jakarta: Paramadina, 2003). 118.

2 Nasr Hamid Abu Zaid, Tekstualitas Alquran: Kritik Terhadap Ulumul Quran (Yogyakarta: IRCiSod, 2016). v.

${ }^{3}$ Mamat S. Burhanudin, Hermeneutika Al-Quran Ala Pesantren (Yogyakarta: UII Press, 2006). 57.

${ }^{4}$ E. Sumaryono, Hermeneutik Sebuah Masalah Metode Filsafat (Yogyakarta: Kanisius, 1999). 23.

${ }^{5}$ Sahiron Syamsudin, Hermeneutika dan Pengembangan Ulumul Qur'an (Yogyakarta: Nawasea Press, 2009). 10.

${ }^{6}$ Burhanudin, Hermeneutika Al-Quran Ala Pesantren. 57.

${ }^{7}$ Muzairi, Hermeneutik dalam Pemikiran Islam (Yogyakarta: Islamika, 2003). 54.

76|Al Amin: Jurnal Kajian Ilmu dan Budaya Islam, Volume 2, No 1, 2019 
makna yang terdapat dalam penafsiran. Sedangkan, kata hermeneutika sebagai kata benda yang mengandung arti sebagai ilmu penafsiran, ilmu untuk mengetahui apa yang terkandung dalam kata-kata dan ungkapan penulis atau penafsiran khusus terhadap Kitab Suci. ${ }^{8}$

Hermeneutika juga sering diartikan sebagai metode pemahaman atas pemahaman (understanding of understanding). ${ }^{9}$ Selain itu, terdapat beberapa definisi modern mengenai hermeneutika yang dicetuskan beberapa tokoh intelektual. Definisi tersebut di antaranya; (1) teori eksegesis Bibel; (2) metodologi filologi secara umum; (3) ilmu pengetahuan linguistik; (4) fondasi metodologis geistewessenshaften; (5) fenomenologi eksistensi dan pemahaman eksistensial; (6) sitem interpretasi, baik recollectif maupun iconoclastic. ${ }^{10}$ Beberapa definisi ini menggambarkan kompleksitas akan fokus pembahasan hermeneutika. Pada dasarnya hermeneutika merupakan salah satu teori filsafat mengenai interpretasi makna. ${ }^{11}$ Secara lebih jauh makna hermeneutika sebagai sebuah ilmu dan seni membangun makna melalui interpretasi rasional dan imajinatif dari bahan baku berupa teks. ${ }^{12}$

Disisi lain, hermeneutika dikenal sebagai sebuah metode yang merujuk pada impelementasinya dalam konteks memahami. Untuk memperjelas konteks ini, di sini Wilhelm Dilthey memberikan pandangan untuk dapat membedakan ilmu alam yang menggunakan metode erklaren (menjelaskan hubungan kausalitas) dengan ilmu kemanusiaan yang menggunakan metode versthen (memahami). ${ }^{13}$ Apa yang ingin diketahui dari versthen bukanlah hubungan kausalitas belaka, tetapi merujuk pada makna-makna yang terdapat di dalam pengalaman dan struktur simbolis yang dihasilkan di dunia ini sebagai realitas. ${ }^{14}$

Selain itu, sebagai bagian dari versthen, tugas pokok hermeneutika untuk bagaimana menafsirkan sebuah teks klasik atau realitas sosial di masa lampau yang asing sama sekali agar menjadi milik orang yang hidup di masa, tempat, dan suasana kultural yang berbeda. ${ }^{15}$ Konteks hermeneutika mempelajari masa lampau menunjukkan hermeneutika sebagai ilmu yang mempelajari sejarah pada umumnya. ${ }^{16}$ Hal ini sebagai pendapat Dilthey yang diperkuat oleh Bultmann. Oleh sebab itu, bagi Bultmann istilah hermeneutika selalu diartikan sebagai exegesis of an historically transmitted text. ${ }^{17}$

Lebih jauh lagi, Bultmann mengembangkan teori umum tentang interpretasi teks. Pertama, semua interpretasi dokumen-dokumen tertulis harus dianalisis secara formal

\footnotetext{
${ }^{8}$ Fakhrudin Faiz, Hermeneutika Qurani: Antara Teks, Konteks, dan Kontekstualitas (Yogyakarta: Qalam, 2003). 20.

${ }^{9}$ Edi Mulyono dkk., Belajar Hermeneutika: Konfigurasi Filosofis Menuju Praksis Islamic Studies (IRCiSoD, 2013). 100.

${ }^{10}$ Richard E. Palmer, Hermeneutics Interpretation Theory in Schleirmacher, Dilthley, Heidegger, and Gadamar (Evanstone: Northwestern University Pres, 1969). 38.

${ }^{11}$ Arip Purkon, "Pendekatan Hermeneutika dalam Kajian Hukum Islam," Ahkam XIII, no. 2 (Juli 2013). 183-192, 184 .

12 Sulaiman Ibrahim, "Hermeneutika Teks: Sebuah Wacana dalam Metode Tafsir Al-Quran," Hunafa: Jurnal Studia Islamika 11, no. 1 (Juni 2014). 23-41, 27.

13 Budiman Hardiman, "Ilmu-Ilmu Sosial dalam Diskursus Modernisme dan Post-Modernisme," Suplemen Ulumul Quran 5, no. 1 (1994). 1-15, 6.

14 Budiman Hardiman, "Positivisme dan Hermeneutik: Suatu Usaha Menyelamatkan Subyek," Basis, Maret 1991. 87-101, 94. Studies. 101

15 Edi Mulyono dkk., Belajar Hermeneutika: Konfigurasi Filosofis Menuju Praksis Islamic

${ }^{16}$ Rudolf Bultmann, Essay, Philosophical and Theological (London: SCM Press, 1955). 235. Gadamar. 50.

17 Palmer, Hermeneutics Interpretation Theory in Schleirmacher, Dilthley, Heidegger, and
} 
dalam struktur dan gaya bahasanya. Aturan hermeneutika semacam ini akan melahirkan metode historis tentang pendalaman teks, yang pada gilirannya mengandung pernyataan bahwa sejarah sebagai satu kesatuan dalam pengertian rangkaian tertutup, di mana peristiwa-peristiwa individual dihubungkan dengan munculnya sebab akibat. ${ }^{18}$

Kedua, penafsir harus memiliki relasi hidup dengan sesuatu yang dinyatakan sebuah teks. Hal ini menjadi penting, di mana sebuah teks setidaknya menjadi salah satu pengalaman nyata sebagai bentuk relasinya. Bila tidak terdapat relasi, maka tidak mungkin terjadi penyelidikan dan pemahaman yang memadai. ${ }^{19}$ Penafsir paling tidak merasakan pengalaman yang sama dengan keadaan pada waktu dokumen tersebut dibuat. ${ }^{20}$

Berdasarkan penjelasan di atas, dapat dinyatakan bahwa kegiatan hermeneutika selalu bersifat triadik. Maksud triadik disini adalah menyangkut pada tiga subjek yang saling berhubungan satu sama lain. Tiga subjek tersebut meliputi the world of the text (dunia teks), the world of the author (dunia pengarang), dan the world of the reader (dunia pembaca), di mana masing-masing memiliki titik pusaran tersendiri dan saling mendukung dalam memahami sebuah teks. ${ }^{21}$ Secara sederhana, di dalam hermeneutika terdapat unsur teks, pemilik teks, yakni sebagai pengarang, serta pembaca, di mana bertugas untuk melakukan penafsiran.

\section{AKAR KESEJARAHAN HERMENEUTIKA}

Istilah hermeneutika tidak lahir secara instan dalam kajian ilmiah. Dalam kesejarahannya, istilah hermeneutika merujuk pada mitos Hermes (Dewa Yunani) yang bertugas menyampaikan berita dari Sang Maha Dewa kepada umat manusia. ${ }^{22}$ Menurut Hossein Nasr sebagaimana dikutip oleh Komarudin Hidayat, Hermes tidak lain adalah Nabi Idris A.s. yang disebut dalam Alquran. ${ }^{23}$

Sementara itu, pengetahuan dalam pesantren mengenai Nabi Idris A.s. dikenal sebagai seorang tukang tenun. Profesi atau pekerjaan Nabi Idris A.s. jika dikaitkan dengan mitos Hermes, memiliki korelasi positif. Kata kerja menenung atau memintal yang dalam bahasa Yunani adalah tegere, sedangkan produknya disebut textus atau text, di mana merupakan isu sentral yang dalam kajian hermeneutika dinisbahkan pada Hermes. Bagi Nabi Idris as atau Hermes persoalan pertama yang dihadapi adalah bagaimana menyampaikan pesan-pesan Tuhan yang disampaikan dengan bahasa langit agar bisa dipahami manusia yang berbicara dengan bahasa bumi. ${ }^{24}$ Nabi Idris A.s. atau Hermes diasosiasikan mentransmisi apa yang ada dibalik pemahaman manusia ke dalam suatu bentuk, di mana intelegensia manusia dapat menangkap hal tersebut. ${ }^{25}$

Kesejarahan hermeneutika tidak terlepas dari proses interaksi keilmuan yang terus mengalami pasang surut. Secara periodisasi, kesejarahan hermeneutika terbagi dalam tiga fase, yakni klasik, pertengahan dan modern. ${ }^{26}$ Pertama, hermeneutika klasik. Pada fase

${ }^{18}$ Bultmann, Essay, Philosophical and Theological. 250.

${ }^{19}$ Bultmann. 252.

20 Edi Mulyono dkk., Belajar Hermeneutika: Konfigurasi Filosofis Menuju Praksis Islamic Studies. 103.

21 Komarudin Hidayat, Memahami Bahasa Agama: Sebuah Kajian Hermeneutik (Jakarta: Paramadina, 1996). 3.

${ }^{22}$ Ibrahim, "Hermeneutika Teks: Sebuah Wacana dalam Metode Tafsir Al-Quran." 23-41, 27.

${ }^{23}$ Komaruddin Hidayat, Menafsirkan Kehendak Tuhan (Jakarta: Teraju, 2003). 147.

24 Hidayat. 147.

25 Edi Mulyono dkk., Belajar Hermeneutika: Konfigurasi Filosofis Menuju Praksis Islamic Studies. 36.

${ }^{26}$ Edi Mulyono dkk. 34.

78|Al Amin: Jurnal Kajian Ilmu dan Budaya Islam, Volume 2, No 1, 2019 
ini hermeneutika lebih bercorak kepada interpretasi teks dan art of interpretation. Pada dasarnya istilah ini muncul pertama kali pada abad ke-17. Pada fase ini terjadi pergulatan awal bagaimana hermeneutika itu lahir dan berkembang dalam kajian ilmiah, yang kemudian melahirkan gagasan-gagasan ilmiah pada fase berikutnya.

Kedua, hermeneutika pertengahan. Pada fase ini hermeneutika dimulai dan dianggap dari penafsiran terhadap Bible yang menggunakan empat level pemaknaan baik secara literal, allegoris, tropologikal (moral), dan eskatologis. Akan tetapi, pada masa reformasi Protestan, empat pemaknaan itu kemudian disempitkan pada eksegesis literal atau gramatikal dan eksegesis studi tentang Yahudi dan Yunani. Adapun pendapat lain mengenai komponen dalam studi Bibel ini mengandung lima komponen pembahasan dalam hermeneutika, yakni literatur (teks), analisis gramatikal, analisis sejarah, analisis kontekstual, dan analisis kontekstual. ${ }^{27}$ Menurut Sulaiman Ibrahim pada fase ini adanya proses dan interaksi implementasi hermeneutika terhadap teks-teks kitab suci untuk menginterpretasikan Bibel disebut sebagai ilmu tafsir kitab suci. ${ }^{28}$

Ketiga, hermeneutika modern. Pada fase ini terdapat perkembangan beberapa aliran hermeneutika. Masa fase awal dimulai pada abad ke-19 dengan merujuk pada tokoh Protestan ternama, Friedrich Schleiermacher dan murid-muridnya termasuk Emilio Betti dengan gagasannya tentang hermeneutical theory. Masa fase kedua dimulai pada abad ke-20 dengan Martin Heidegger sebagai tokohnya, termasuk juga terdapat Hans George Gadamer dengan gagasannya tentang aliran filsafat hermeneutik, dan terakhir terdapat Jurgen Habermas dengan hermeneutik kritiknya. ${ }^{29}$

Melacak pada kesejarahan Islam klasik, sesungguhnya Muhammad Abduh sebagai pembaharu Islam mengeluarkan gagasannya. Menurut Muhammad Abduh perlunya penafsiran atau interpretasi baru terhadap ajaran-ajaran dasar Islam (al-Quran), di mana harus disesuaikan dan sejalan dengan tuntutan zaman. ${ }^{30}$ Gagasan ini tentunya muncul untuk menjawab tantangan zaman yang semakin berkembang secara kompleks. Secara fakta sosial, proses turunnya al-Quran sebagai wahyu telah berhenti, tetapi problematika sosial semakin perkembang, di sinilah peran penafsiran kontekstualisasi Alquran.

Penggambaran periodisasi kesejarahan hermeneutika di atas telah memberikan adanya kecenderungan corak dan karakteristik yang distingtif akan masa lahirnya hermeneutika itu sendiri. Hal ini menjadi cikal bakal akan perkembangan hermeneutika pada masa periode selanjutnya yang mulai menyentuh kepada ranah sosial kemasyarakatan sebagai objek kajiannya. Adapun ilmu-ilmu yang berkaitan erat dengan hermeneutik di antaranya; sejarah, hukum, kesusasteraan, dan lain sebagainya yang menyangkut dengan ilmu pengetahuan tentang kemanusiaan (ilmu-ilmu sosial). ${ }^{31}$ Akan tetapi, pada dasarnya hermeneutika sebagai sebuah aktivitas penafsiran telah lahir jauh sebelumnya, di mana usianya setua dengan eksegesis teks. ${ }^{32}$ Hanya saja saat itu, penyematan istilah hermeneutika belum disematkan di dalamnya sebagai konteks untuk mengkaji teks.

27 Muhammad Widus Sempo dan Noor Azma Mohamad K., "Eskplorasi Epistimologi Hermeneutika Vs Tafsir: Kajian Perbandingan," Ulum Islamiyyah 20 (April 2017). 85-94, 86-87.

${ }^{28}$ Ibrahim, "Hermeneutika Teks: Sebuah Wacana dalam Metode Tafsir Al-Quran." 23-41, 26.

29 Edi Mulyono dkk., Belajar Hermeneutika: Konfigurasi Filosofis Menuju Praksis Islamic Studies. 35.

${ }^{30}$ Rif'at Syauqi Nawawi, Rasioanlitas Tafsir Muhammad Abduh: Kajian Masalah Aqidah dan Ibadah (Jakarta: Paramadina, 2002). 5.

${ }^{31}$ M. Alfatih S., "Metode Hermeneutik dalam Pensyarahan Hadis," Jurnal Studi Ilmu-Ilmu AlQuran dan Hadis 1, no. 2 (2001). 35-49, 39.

${ }^{32}$ Roger Fowler, ed., A Dictionary of Modern Critical Term (London and New York: Routledge and Kegan Paul, 1987). 109. 


\section{KONTROVERSI IMPLEMENTASI HERMENEUTIKA TERHADAP AL-QURAN}

Persoalan teks-teks yang ada di dalam al-Quran selalu berkembang. Hal ini menjadikan bukti bahwa studi atas teks-teks al-Quran tidak berhenti, tetapi justru mengalami pembaharuan makna secara kontekstual. Seperti diketahui bahwa bahasa Arab menjadi bahasa di dalam al-Quran. Bahasa Arab merupakan bahasa teritorial di mana al-Quran diturunkan. Tentunya ini dimaksudkan agar bahasa Alquran mudah dipahami oleh masyarakat Arab saat itu. Namun, justru bahasa Alquran tidak semudah memahami bahasa Arab pada umumnya, di mana bahasa Alquran memiliki distingsi tersendiri, serta perlu dipahami secara saksama, tidak hanya menggunakan rasionalitas ilmu, tetapi juga kedalaman ruhani untuk menyelami bahasa yang disampaikan Tuhan sebagai wahyu.

Pemaknaan dalam bahasa Arab terdapat makna haqiqi (makna asli) dan makna majazi (makna metaforik). Di dalam makna haqiqi saja terdapat tiga pilihan makna, yakni haqiqah lugawiyah (etimologis), haqiqah 'urfiyyah (tradisional), dan haqiqah shar'iyyah (terminologis keagamaan). ${ }^{33}$ Selain itu, makna majazi terdiri juga dari majaz. mursal, majaz isti'arah, dan lain sebagainya. ${ }^{34}$ Makna tersebut tentu perlu pendalaman sebagai bentuk penafsiran atas teks-teks yang zanni, kecuali tidak bagi teks-teks yang sudah pasti atau absolut (qat'i).

Penafsiran terhadap Alquran ini yang kemudian mengalami kemelut ilmiah pasca masuknya metode hermeneutika dalam menafsirkan al-Quran. Para ulama yang sebelumnya melakukan pembakuan terhadap model penafsiran al-Quran merasa adanya problem tersendiri terhadap penerapan metode hermeneutik itu sendiri. Proses penafsiran terhadap al-Quran, ulama terdahulu misalnya menggunakan metode $t a$ 'wil, di mana pada awalnya ta'wil sebagai bentuk sintaksis yang menjelaskan lafal dan susunan yang klasik melalui lafal dan susunan yang baru demi menjaga maknanya agar relevan dengan zaman. $^{35}$

Dalam metode ta'wil tersebut para ulama memiliki pandangan yang berbeda. Pertama, kelompok konvensional. Kelompok ini diwakili ulama klasik, di mana membakukan makna semantik tertentu dan tidak mudah masuk ke wilayah majaz. Kedua, kelompok modernistik. Kelompok ini diwakili oleh ulama yang mengatasnamakan cendekiawan bebas tanpa dibatasi sakralitas teks, di mana ta'wil diidentikkan dengan hermeneutika barat yang syarat dengan ide dan filosofis dunia barat. Bahkan, Nasr Hamid Abu Zaid menyatakan dengan tegas bahwa ta'wil yang dipakai untuk memahami teks di dunia Islam adalah hermeneutika dalam dunia barat yang sering dipakai untuk memahami teks Bibel dan Kitab Suci lainnya. ${ }^{36}$ Di sisi lain, menurut Quraish Shihab, tidaklah keliru bahwa sebenarnya hermeneutika telah dikenal oleh para ulama jauh sebelum kemunculannya di barat. ${ }^{37}$ Dalam konteks ini Quraish Shihab menganggap bahwa hermeneutika sebagai wajah dari tafsir dan ta'wil. Kelompok kedua ini yang dalam Islam mendukung pandangan hermeneutika terhadap penafsiran yang ada di dalam al-Quran.

${ }^{33}$ Ach. Maimun, "Resistensi Hermeneutika dalam Kajian Al-Quran di Indonesia," Suhuf 8, no. 2 (Juni 2015). 233-260, 234-235.

${ }^{34}$ Fahmi Salim, Kritik terhadap Studi Al-Quran Kaum Liberal (Jakarta: Gema Insani, 2010). 43.

${ }^{35}$ Mustafa al-Kailani, Wujud al-Nass, Nass al-Wujud (Tunisia: Dar al-Tunisiyah, 2003). 34.

36 Abd. Razzaq dan Deden Mula Saputra, "Studi Analisis Komparatif Antara Ta'wil dan Hermeneutika dalam Penafsiran Al-Quran," Wardah 17, no. 2 (Desember 2016). 89-114, 104.

${ }^{37}$ M. Quraish Shihab, Membumikan Al-Quran: Memfungsikan Wahyu dalam Kehidupan (Jakarta: Lentera Hati, 2011). 555.

80|Al Amin: Jurnal Kajian Ilmu dan Budaya Islam, Volume 2, No 1, 2019 
Namun, terdapat pula penolakan-penolakan terhadap hermeneutika. Penolakan ini pada dasarnya bukan tanpa sebab semata. Terdapat tiga argumen yang membangun fondasi penolakan hermeneutika dalam Islam. Pertama, argumen ideologis. Pada argumen ini mempersoalkan asal muasal hermeneutika yang berasal dari barat, atau meminjam istilah Fahmi Salim disebut sebagai pemikiran impor. ${ }^{38} \mathrm{Hal}$ ini menunjukkan bukti adanya sentimen yang tinggi terhadap pemikiran barat. Bahkan, pemikiran barat juga dianggap tidak sesuai dengan ajaran Islam selama ini. Beberapa pemikiran barat yang cukup mendapat sorotan seperti pemikiran liberalisme, sekularisme, pluralisme, serta yang paling mengancam imperialisme dan kolonialisme. ${ }^{39}$ Argumen ini juga menganggap pemikiran orientalis barat dinilai secara negatif.

Kedua, argumen teologis. Dalam argumen ini terdapat anggapan bahwa teori-teori yang berkembang di dalam hermeneutika justru berseberangan dengan aspek teologi di dalam Islam. Hal itu seperti pandangan bahwa al-Quran dianggap sebagai produk budaya, teks bahasa linguistik, dan teks manusiawi, di mana justru di dalam Islam, alQuran dianggap sebagai firman Allah Swt yang transhistoris, tidak dilahirkan oleh budaya, karenanya tidak bisa disamakan dengan teks lain yang disusun manusia. ${ }^{40}$ Selain itu, dalam argumen ini hermeneutika juga dianggap menggugat otentisitas al-Quran.

Ketiga, argumen epistimologis. Pada argumen ini berkaitan dengan problematika epistimologi dalam hermeneutika yang kemudian diintrodusir ke dalam pemahaman alQuran, yakni tentang relativitas pemahaman. Al-Quran dianggap sebagai teks suci dari segi mantuq-nya, tetapi menjadi relatif dari segi mafhum-nya, di mana mafhum telah melibatkan manusia yang serba relatif. ${ }^{41}$ Pada dasarnya relativisme dapat mengubah ajaran yang telah disepakati sebelumnya. Relativisme bukan sekadar mengancam Alquran sebagai teks yang ditafsirkan, tetapi lebih jauh akan memberangus ajaran yang telah dirumuskan dari penafsiran yang telah diakui secara final dan disepakati sebagai doktrin. ${ }^{42}$ Didalam relativisme terdapat anggapan tidak ada final di dalam sebuah penafsiran.

Untuk melihat konteks argumen epistemologi di atas, terdapat beberapa aspek perbedaan Alquran dan Bibel yang menutup kemungkinan hermeneutika di dalam alQuran, yakni; (1) Al-Quran disepakati sebagai firman Allah Swt., sedangkan Bibel telah dinyatakan sebagai karangan manusia; (2) Al-Quran masih dalam bahasa asli, sedangkan Bibel telah ditulis dalam berbagai bahasa; (3) untuk memahami Alquran dibutuhkan tafsir dan ta'wil, serta tidak membutuhkan kritik tekstual sebagaimana yang dibutuhkan Bibel; (4) untuk memahami al-Quran telah ada metode baku yang tidak berseberangan, sedangkan memahami Bibel terdapat banyak aliran yang justru bersebarangan; (5) Di dalam al-Quran terdapat makna yang jelas (muhkam), tidak jelas maknanya (mutashabih), absolut (qat'i), dan relatif (zanni), sedangkan dalam hermeneutika semua teks dianggap relatif-interpretatif. ${ }^{43}$

Selain itu, dalam pandangan Quraish Shihab, hermeneutika ketika berhadapan dengan Bibel akan mengalami kecurigaan tersendiri. Hal itu dikarenakan Bibel berbeda dengan Alquran, di mana terdapat kritik sejarah dan penulisannya juga terjadi jauh setelah kepergian Nabi Isa A.s. Sedangkan. Al-Quran menurut Quraish Shihab jika

\footnotetext{
${ }^{38}$ Salim, Kritik terhadap Studi Al-Quran Kaum Liberal. 89.

${ }^{39}$ Maimun, "Resistensi Hermeneutika dalam Kajian Al-Quran di Indonesia." 233-260, 239.

${ }^{40}$ Maimun. 233-260, 240.

${ }^{41}$ Maimun. 233-260, 240.

${ }^{42}$ Salim, Kritik terhadap Studi Al-Quran Kaum Liberal. 89.

${ }^{43}$ Ugi Suharto, "Apakah Alquran Memelurkan Hermeneutika," Islamia, 1, 1, no. 1 (Maret 2004).
} 41-55. 49. 
dihadapkan dengan hermeneutika justru tidak ada lagi kecurigaan menyangkut teks didalamnya, semuanya dianggap otentik dan benar pada tempatnya. ${ }^{44}$

Adanya polemik penerapan hermeneutika tidak terlepas dari proses upaya mempertahankan metode ilmiah di dalam Islam sekaligus mempertahankan otentisitas dan otoritas di dalam al-Quran. Hal di atas hanya menunjukkan terjadinya dinamika yang tajam dalam menerapkan hermeneutika. Meski tidak semuanya menunjukkan penolakan, tetapi eksistensi hermeneutika didalam Islam belakangan mendapat sorotan tajam untuk terus dikembangkan secara signifikan. Tentunya dibatasi dengan koridor-koridor tertentu.

\section{E. FORMULASI PENAFSIRAN AL-QURAN PERSPEKTIF HERMENEUTIKA}

Terlepas dari polemik dan kontroversi penerapan hermeneutika terhadap Alquran, sejatinya hermeneutika tetap memiliki daya tarik dan distingsi tersendiri sebagai metode penafsiran. Hal ini menunjukkan eksitensi hermeneutika tidak diragukan lagi. Meskipun populer di dunia barat, kepopuleran hermeneutika di dunia Islam juga mulai mendapat tempat untuk dikaji dan diterapkan secara ilmiah.

Dalam konteks pemikiran Islam, hermeneutika memiliki daya tarik tersendiri terhadap minat intelektual Muslim. Hal ini terjadi karena terdapat tiga alasan. Pertama, adanya stagnasi teks (khususnya Alquran) dan dinamika realitas. Tidak dapat dipungkiri bahwa jika penafsiran Alquran tidak dikembangan sesuai zaman justru membuatnya menjadi tidak berkembang. Disisi lain, dinamika realitas sosial memerlukan penyegaran akan ajaran al-Quran. Oleh sebab itu, untuk tetap menghidupkan teks diperlukan dinamika penafsiran demi mengimbangi dinamika realitas, serta hermeneutika dinilai menjanjikan jalan yang prospektif untuk itu. ${ }^{45} \mathrm{Kedua}$, teks sebagai objek hermeneutika. Maka cukup memungkinkan jika hermeneutika digunakan dalam penafsiran al-Quran, karena hermeneutika menafsirkan teks, sebagaimana tafsir dan ta'wil. Ketiga, bahasa Arab sebagai bahasa manusia. Artinya, bahasa Arab di dalam al-Quran merupakan bahasa manusia yang dapat ditafsirkan oleh manusia pula. Tiga alasan tersebut menjadi instrumen penting melahirkan pengakuan studi hermeneutika didalam Islam.

Namun, untuk menerapkan hermeneutika di dalam Islam perlu memperhatikan tiga hal penting. ${ }^{46}$ Pertama, akomodasi yang sesuai. Dalam konteks ini, proses akomodasi teori-teori di dalam hermeneutika dengan memperhatikan aspek kesesuain agar tidak berseberangan dengan apa yang ada di dalam Islam. Kedua, modifikasi yang kurang sesuai. Artinya, teori-teori hermeneutika yang tidak sesuai dengan Islam perlu diupayakan untuk dilakukan inovasi agar bisa diterapkan di dalam Islam dalam menafsirkan al-Quran. Ketiga, resistensi yang tidak sesuai. Jika upaya memodifikasi tidak bisa dilaksanakan, maka teori-teori yang tidak sesuai perlu ditinggalkan.

Beberapa contoh intelektual Muslim yang menerapkan tiga hal penting di atas di antaranya; Fazlurrahman dengan teori double movement yang memadukan filsafat hukum Islam al-Syatibi dengan hermeneutika Emilio Betti. Kemudian terdapat pula Muhammad Syahrur sebagai penafsir subjektif dengan pendekatan linguistik-saintifik yang melahirkan teori limit (nazariyat al-hudud). ${ }^{47}$ Selain itu, terdapat pula Nasr Hamid Abu Zaid sebagai penganut hermeneutika inklusif melalui pendekatan kesusteraan dengan

\footnotetext{
${ }^{44}$ Shihab, Membumikan Al-Quran: Memfungsikan Wahyu dalam Kehidupan. 557-558.

${ }^{45}$ Syamsudin, Hermeneutika dan Pengembangan Ulumul Qur'an. 26.

${ }^{46}$ Maimun, "Resistensi Hermeneutika dalam Kajian Al-Quran di Indonesia." 233-260, 238.

${ }^{47}$ Abd. Mustaqim, Epistimologi Tafsir Kontemporer (Yogyakarta: LKiS, 2009). 98.
} 
meminjam teori Hirch yang membagi makna menjadi dua, yakni objektif ( $m a$ 'na) dan signifikansi $(\text { magza })^{48}$

Terdapat pula Abou el-Fadl yang menggunakan hermeneutik negosiatif, di mana makna merupakan hasil interaksi yang kompleks antara pengarang, teks, dan pembaca yang selalu diperdebatkan, dinegosiasikan, dan terus mengalami perubahan. Apa yang diupayakan el-Fadl untuk melawan hegemoni otoritarisme interpretatif, di mana teks diberangus oleh penafsir otoriter. ${ }^{49}$ Kemudian ada pula, Muhammad Syahrur juga menggunakan hermeneutika dengan pembacaan hermeneutik kontemporer, yang bertumpu pada dialektika being, process, dan becoming. Tentu masih banyak tokohtokoh intelektual Muslim yang mengupayakan penggunaan hermeneutika dalam teks Alquran.

Dalam menerapkan hermeneutika terhadap penafsiran al-Quran tidak mudah tanpa mengetahui secara mendalam aspek disiplin keilmuan, baik dari segi disiplian keilmuan Islam, termasuk pula disiplin keilmuan dari hermeneutika itu sendiri. Quraish Shibab telah memberikan solusi model dalam menerapkan hermeneutika untuk menafsirkan alQuran. Menurutnya, penggunaan hermeneutika memungkinkan upaya untuk dapat menarik makna. Hanya saja syarat yang ditetapkan dalam kebolehan menggunakan hermeneutika beragam antara ketat dan longgar.

Pendapat yang ketat mengingatkan bahwa baru boleh menggunakan hermeneutika kalau ada qarinah yang pasti menghalangi makna zahir-nya, serta makna yang dipilihpun harus telah dikenal oleh pengguna bahasa Arab pada masa turunnya Alquran saat itu. Sedangkan, pendapat yang longgar menyatakan bahwa penggunaan hermeneutika dengan syarat adanya makna yang dipilih dapat dikembalikan kepada akar kata yang dita'wilkan. ${ }^{50}$

Di sisi lain, Quraish Shihab juga memberikan kritik atas penerapan hermeneutika yang secara tidak tepat, di mana justru hal itu dapat merugikan. Menurutnya, dengan mengalihkan makna tanpa qarinah yang ada di dalam Alquran, serta hanya sekadar memuaskan nalar penafsir tentu saja hal itu tidak dibenarkan oleh para ulama. Lebih jauh lagi, Quraish Shihab menyatakan penafsiran semacam itu telah digunakan oleh sementara orang atas nama hermeneutika. ${ }^{51}$ Disini dapat dipahami bahwa upaya penafsiran dengan hermeneutika yang tidak tepat masih berlangsung disebagian penafsir. Tentunya hal ini perlu mendapat perhatian lebih.

Model sekaligus kritik yang diajukan Quraish Shihab di atas memberikan gambaran yang jelas bahwa upaya penerapan hermeneutika tidak sertamerta dapat dilaksanakan begitu saja, tanpa melihat aturan-aturan yang perlu dipatuhi. Hal ini dilakukan untuk menjaga kehati-hatian dalam menafsirkan al-Quran, sehingga dapat meminimalisir subjektivitas, atau bahkan kekeliruan yang dapat menciderai nilai-nilai yang ada di dalam al-Quran. Kehatian-hatian dalam menafsirkan al-Quran tentu telah menjadi kesepakatan yang baku.

\section{F. HERMENEUTIKA SEBAGAI MODEL ALTERNATIF PENAFSIRAN AL- QURAN}

${ }^{48}$ Nasr Hamid Abu Zayd, Naqd al-Khitab al-Dini (Kairo: Sina li al-Nashr, 1994). 220.

49 Ali Hasan Siswanto, "Hermeneutika Negosiatif Khaled Abou El-Fadl: Menjunjung Otoritas Teks Sekaligus Membatasi Otoritanisme,” t.t., https://researchgate.net/publication/32324216. diakses pada 15/11/2018 pukul 13.00 WIB

${ }^{50}$ Shihab, Membumikan Al-Quran: Memfungsikan Wahyu dalam Kehidupan. 564-565.

${ }^{51}$ Shihab. 565. 
Pasang surut pemahaman al-Quran sebagai teks telah banyak ditafsirkan sebagai ajaran Islam yang baku. Hal ini menjadi model klasik penafsiran di dalam al-Quran yang dilakukan oleh para ulama. Model ini hanya akan mengalami stagnasi jika tidak dikembangkan sesuai dengan perkembangan ilmu pengetahuan dan perubahan zaman, di mana agama dituntut untuk tetap eksis di antara penganutnya, termasuk agama Islam yang ajarannya tertuang di dalam Alquran.

Untuk mengatasi problematika di atas, sejatinya hermeneutika hadir dalam kerangka keagamaan untuk menjaga eksistensi agama itu sendiri. Seperti diketahui pemahaman dan penafsiran al-Quran di masa klasik dilakukan dengan tidak memaksimalkan dari aspek sosial-historisnya. Ketika Alquran dipahami secara terpisah dari konteks sosial-historisnya, banyak aspek dari wacana sosial-psikologisnya yang hilang. ${ }^{52}$

Tanpa disadari atau tidak justru proses penafsiran dapat menimbulkan wacana penyempitan dan penggiringan opini atas makna dan nuansa ajaran agama yang terkandung di dalamnya. Wacana yang seperti ini justru akan menciderai nilai-nilai agama itu sendiri, di mana hal ini menunjukkan aspek politis yang sangat jelas. Hadirnya hermeneutika berupaya menghindari hal tersebut terjadi dalam sebuah penafsiran teks.

Hermeneutika memiliki relevansi dan urgensi sebagai metodologi penafsiran yang dihadirkan dalam memahami al-Quran. ${ }^{53}$ Proyeksi penafsiran hermeneutika terhadap Alquran dengan menitikberatkan pula pada aspek sosial-historisnya dan sosialpsikologisnya, di mana hal ini menjadi ciri utama dari hermeneutika yang menitikberatkan pembahasan pada masa lampau. Hal ini sebagaimana yang dinyatakan dalam tesis Delthey dan diperkuat oleh Bultmann bahwa hermeneutika sebagai ilmu yang mempejari sejarah. ${ }^{54}$

Dalam konteks ini, Fazlurrahman mengajukan kritik historis sebagai upaya dalam melakukan systematic reconstruction, di mana digunakan dalam melihat dialektika pandangan di dalam Alquran dengan tradisi pemikiran Islam. ${ }^{55}$ Terdapat pula Nasr Hamid Abu Zaid yang mengusung kritik wacana agama, yang menyingkap pembedahan ideologis tendensius dan pembacaan yang tanpa melihat historis pada masa sebelumnya. ${ }^{56}$ Upaya untuk melihat sejarah menjadi trend dalam menggunakan hermeneutika.

Titik balik historis menjadi penting untuk melihat sejauh mana polemik yang pernah menyelimuti teks pada masa silam. Tidak dapat dipungkiri bahwa kesejarahan Islam menunjukkan eksistensi Islam yang luar biasa sebagai imperium yang berkuasa. Bahkan, isu politis dalam catatan sejarah juga tidak terlepas dari peran penguasa saat itu. Termasuk pula pola penafsiran saat itu yang mungkin melibatkan isu politis pula. Hal ini tentu menciderai nilai-nilai yang ada di dalam Alquran.

Sebagai sebuah alternatif tentu pelacakan sejarah tidak hanya pada teks saja, tetapi perlu juga melacak kesejarahan akademik penafsirnya. Hal ini dilakukan untuk melihat kompetensi penafsir sekaligus melihat apakah ada unsur lain di dalam menafsirkan teks. Tentunya berkaitan dengan faktor ekonomi, sosial, politik, sehingga dapat menimbulkan kesalahan maupun perbedaan penafsiran. Pelacakan sejarah teks al-Quran tentunya berkaitan dengan bagaimana proses turunnya pada masa itu.

\footnotetext{
52 Ibrahim, "Hermeneutika Teks: Sebuah Wacana dalam Metode Tafsir Al-Quran.” 23-41, 30.

53 Ibrahim. 23-41, 30.

${ }^{54}$ Bultmann, Essay, Philosophical and Theological. 235.

55 Fazlurrahman, Islam dan Modernitas: Tentang Transformasi Intelektual (Bandung: Pustaka, 1995). 195-196.

${ }^{56}$ Zayd, Naqd al-Khitab al-Dini. 12. 
Menurut Quraish Shihab bahwa pengetahuan makna tentang teks hanya dimiliki oleh pemilik teks tersebut. ${ }^{57}$ Dalam hal ini, tentu Tuhan sebagai pemilik teks Kitab Suci sebagai wayhu ilahi. Di sisi lain, dalam kaitannya melihat konteks sejarah sebagai permulaan dalam hermeneutika membutuhkan upaya yang mendalam. Disini hermeneutika hanya berfokus pada teks saja. Persoalan sosok penafsir tentu di luar dari hermeneutika. Akan tetapi, untuk dapat melihat kualitas penafisran teks tentu dapat melihat pada sosok penafsirnya. Dalam konteks tradisi keilmuan Islam, penerapan hermeneutika hanya sebagai alternatif, di mana tidak melepaskan tradisi klasik yang berkembang sebelumnya. Namun, mengupayakan model baru yang sesuai dengan tuntutan zaman.

\section{G. PENUTUP}

Membumikan hermeneutika dalam Islam memang tidak mudah untuk mengaplikasikannya dalam tradisi keilmuan Islam. Hal ini tidak terlepas dari berbagai kontroversi hermeneutika di dalam menafsirkan Alquran. Di sisi lain, terdapat upaya yang dilakukan untuk melakukan akulturasi tradisi keilmuan Islam dan keilmuan hermeneutika itu sendiri. Dalam konteks ini, sebenarnya paradigma hermeneutika dalam menafsirkan al-Quran sejatinya perlu dilihat secara positif. Meskipun mungkin terdapat hal yang negatif, sebisa mungkin hal itu untuk dihindari agar nuansa kepositifan dalam tradisi keilmuan Islam dan hermeneutika tetap terjaga.

\section{DAFTAR PUSTAKA}

Bultmann, Rudolf. Essay, Philosophical and Theological. London: SCM Press, 1955.

Burhanudin, Mamat S. Hermeneutika Al-Quran Ala Pesantren. Yogyakarta: UII Press, 2006.

Edi Mulyono dkk. Belajar Hermeneutika: Konfigurasi Filosofis Menuju Praksis Islamic Studies. IRCiSoD, 2013.

Faiz, Fakhrudin. Hermeneutika Qurani: Antara Teks, Konteks, dan Kontekstualitas. Yogyakarta: Qalam, 2003.

Fazlurrahman. Islam dan Modernitas: Tentang Transformasi Intelektual. Bandung: Pustaka, 1995.

Fowler, Roger, ed. A Dictionary of Modern Critical Term. London and New York: Routledge and Kegan Paul, 1987.

Hardiman, Budiman. "Ilmu-Ilmu Sosial dalam Diskursus Modernisme dan PostModernisme.” Suplemen Ulumul Quran 5, no. 1 (1994).

. "Positivisme dan Hermeneutik: Suatu Usaha Menyelamatkan Subyek." Basis, Maret 1991.

Hidayat, Komaruddin. Menafsirkan Kehendak Tuhan. Jakarta: Teraju, 2003.

Hidayat, Komarudin. Memahami Bahasa Agama: Sebuah Kajian Hermeneutik. Jakarta: Paramadina, 1996.

. Wahyu di Langit, Wahyu di Bumi: Doktrin dan Peradaban Islam di Panggung Sejarah. Jakarta: Paramadina, 2003.

Ibrahim, Sulaiman. "Hermeneutika Teks: Sebuah Wacana dalam Metode Tafsir AlQuran.” Hunafa: Jurnal Studia Islamika 11, no. 1 (Juni 2014).

Kailani, Mustafa al-. Wujud al-Nass, Nass al-Wujud. Tunisia: Dar al-Tunisiyah, 2003.

${ }^{57}$ Shihab, Membumikan Al-Quran: Memfungsikan Wahyu dalam Kehidupan. 560. 
Maimun, Ach. "Resistensi Hermeneutika dalam Kajian Al-Quran di Indonesia." Suhuf 8, no. 2 (Juni 2015).

Mustaqim, Abd. Epistimologi Tafsir Kontemporer. Yogyakarta: LKiS, 2009.

Muzairi. Hermeneutik dalam Pemikiran Islam. Yogyakarta: Islamika, 2003.

Nawawi, Rif'at Syauqi. Rasioanlitas Tafsir Muhammad Abduh: Kajian Masalah Aqidah dan Ibadah. Jakarta: Paramadina, 2002.

Palmer, Richard E. Hermeneutics Interpretation Theory in Schleirmacher, Dilthley, Heidegger, and Gadamar. Evanstone: Northwestern University Pres, 1969.

Purkon, Arip. "Pendekatan Hermeneutika dalam Kajian Hukum Islam." Ahkam XIII, no. 2 (Juli 2013).

Razzaq, Abd., dan Deden Mula Saputra. "Studi Analisis Komparatif Antara Ta'wil dan Hermeneutika dalam Penafsiran Al-Quran." Wardah 17, no. 2 (Desember 2016).

S., M. Alfatih. "Metode Hermeneutik dalam Pensyarahan Hadis." Jurnal Studi Ilmu-Ilmu Al-Quran dan Hadis 1, no. 2 (2001).

Salim, Fahmi. Kritik terhadap Studi Al-Quran Kaum Liberal. Jakarta: Gema Insani, 2010.

Sempo, Muhammad Widus, dan Noor Azma Mohamad K. "Eskplorasi Epistimologi Hermeneutika Vs Tafsir: Kajian Perbandingan." Ulum Islamiyyah 20 (April 2017).

Shihab, M. Quraish. Membumikan Al-Quran: Memfungsikan Wahyu dalam Kehidupan. Jakarta: Lentera Hati, 2011.

Siswanto, Ali Hasan. "Hermeneutika Negosiatif Khaled Abou El-Fadl: Menjunjung Otoritas Teks Sekaligus Membatasi Otoritanisme," t.t. https://researchgate.net/publication/32324216.

Suharto, Ugi. “Apakah Alquran Memelurkan Hermeneutika.” Islamia, 1, 1, no. 1 (Maret 2004).

Sumaryono, E. Hermeneutik Sebuah Masalah Metode Filsafat. Yogyakarta: Kanisius, 1999.

Syamsudin, Sahiron. Hermeneutika dan Pengembangan Ulumul Qur'an. Yogyakarta: Nawasea Press, 2009.

Zaid, Nasr Hamid Abu. Tekstualitas Alquran: Kritik Terhadap Ulumul Quran. Yogyakarta: IRCiSod, 2016.

Zayd, Nasr Hamid Abu. Naqd al-Khitab al-Dini. Kairo: Sina li al-Nashr, 1994. 
Kamarusdiana, Ahmad Zaki M

Al Amin: Jurnal Kajian Ilmu dan Budaya Islam, Volume 2, No 1, 2019|87 